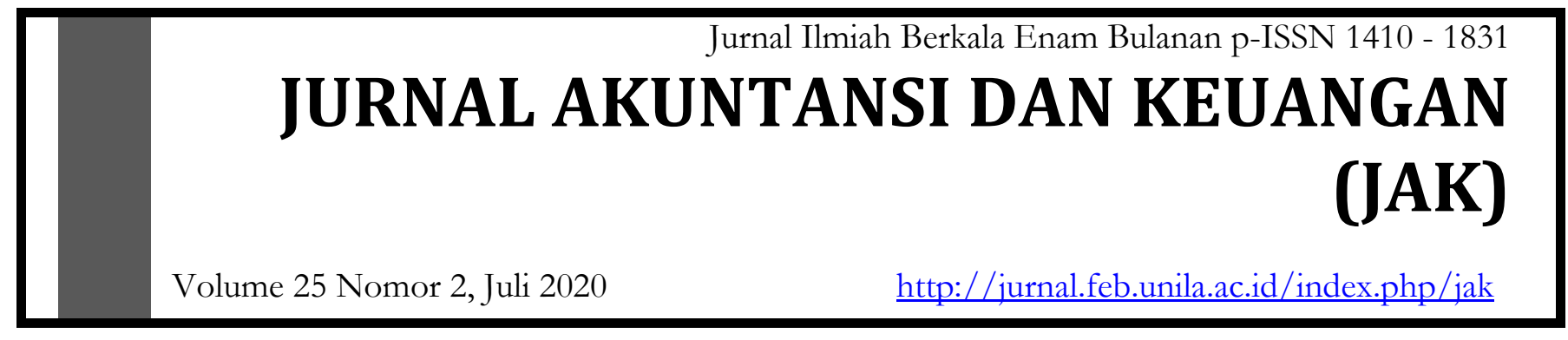

\title{
ANALISIS PENGARUH KEPEMILIKAN MANAJERIAL, CASH RATIOI, DEBT TO EQUITY RATIO DAN GROWTH OPPORTUNITY TERHADAP KEBIJAKAN DIVIDEN
}

\author{
Citra Ayu Wulansari ${ }^{1}$,Reni Oktavia ${ }^{2}$, Farichah ${ }^{3}$, dan Ninuk Dewi Kusumaningrum ${ }^{4}$ \\ ${ }^{1}$ Fakultas Ekonomi dan Bisnis, Universitas Lampung \\ 2 Fakultas Ekonomi dan Bisnis, Universitas Lampung \\ 3 Fakultas Ekonomi dan Bisnis, Universitas Lampung \\ 4 Fakultas Ekonomi dan Bisnis, Universitas Lampung
}

\section{Informasi Naskah}

\section{Update Naskah:}

Update Naskah:

Dikumpulkan: 9 Maret 2020

Diterima: 20 A pril 2020

Terbit/Dicetak: 17 Juli 2020

\section{Keywords:}

Dividend policy, managerial ownership, cash ratio, debt to equity ratio, and growth opportunity

\section{Abstract}

The research aims to examine the effect of managerial ownership, cash ratio, debt to equity ratio, and growth opportunity on dividend policy. The sample in this study was selected using purposive sampling and obtained 150 samples of companies listed on the Indonesia Stock Exchange in 20132018 that met the criteria. The results of hypothesis testing with multiple linear regression analysis using the SPSS 25 application show that managerial ownership, cash ratio, debt to equity ratio, and growth opportunity simultaneously have a significant effect on dividend policy. Partially, managerial ownership has a positive but not significant effect on dividend policy and cash ratio has a significant effect with a positive coefficient on dividend policy. While the debt to equity ratio, and growth opportunity have a significant effect with a negative coefficient on dividend policy. 


\section{A. PENDAHULUAN}

\section{Latar Belakang}

Perusahaan dalam pengelolaannya membutuhkan dana yang besar untuk mengembangkan dan mengoperasikan usahanya. Dana yang diperoleh perusahaan didapat dari pihak internal maupun pihak eksternal perusahaan. Dana yang diperoleh dari pihak eksternal perusahaan berupa hutang (kredit) atau pinjaman lainnya dari bank dan lembaga keuangan bukan bank (kreditor). Dana yang diperoleh dari pihak eksternal, perusahaan memiliki kewajiban untuk membayar utangnya dan dengan bunga yang dibebankan. Sedangkan dana yang diperoleh dari pihak internal perusahaan berasal dari penerbitan saham. Dengan penerbitan saham perusahaan tidak memiliki kewajiban utuk membayar hutang pokok dan bunga yang dibebankan seperti halnya hutang pada pihak kreditor, melainkan memiliki kewajiban lain berupa membayarkan keuntungan perusahaan berupa dividen yang dibagikan kepada pihak investor.

Meilani dan Amboningtyas (2017) menyatakan bahwa investor (pemegang saham) mempunyai tujuan utama dalam menanamkan dananya kedalam perusahaan yaitu untuk mencari pendapatan atau tingkat kembalian investasi (return) baik berupa pendapatan dividen (dividend yield) maupun pendapatan dari selisih harga jual saham terhadap harga belinya (capital gain).Seperti halnya yang terjadi pada kasus PT Freeport berikut. Harapan Indonesia untuk mendapatkan dividen dari hasil kinerja PT Freeport Indonesia di tahun 2014 bakal kembali pupus. Perusahaan tambang itu tidak lagi memberikan bagi hasil dividen kepada para pemegang sahamnya lantaran masih fokus untuk investasi tambang bawah tanah (underground mining).Dengan demikian, kebijakan untuk tidak memberikan dividen ini merupakan tahun ketiga bagi pemerintah menahan dahaga atas bagi hasil dividen Freeport. Terakhir, tahun pada 2011, pemerintah masih mengantongi dividen sebesar US\$ 202 juta atau senilai Rp 1,76 triliun (Hardianto, 2015).

Kasus tersebut sesuai dengan penjelasan Husnan (1998) mengemukakan bahwa perusahaan lebih menyukai untuk menjadikan keuntungan sebagai laba ditahan daripada harus membagikannya kepada pemegang saham dalam bentuk dividen, sedangkan pemegang saham lebih tertarik jika dividen tersebut dibagikan daripada menundanya. Oleh karena itu terdapat keputusan yang berlawanan antara perusahaan dengan pemegang saham, sehingga perusahaan dituntut untuk mengambil langkah bijak dalam pembagian dividen agar bisa membawa keuntungan bagi investor dilain sisi dapat membawa manfaat untuk keberlangsungan kegiatan perusahaan.

Hasil yang tidak konsisten dari penelitian sebelumnya menjadi motivasi peneliti untuk melakukan penelitian mengenai kebijakan dividen pada perusahaan non-keuangan di Indonesia.Uraian di atas yang mendasari penulis melakukan penelitian yang berjudul "Analisis Pengaruh Kepemilikan Manajerial, Cash Ratio, Debt To Equity Ratio, dan Growth Opportunity Terhadap Kebijakan Dividen".

\section{Rumusan Masalah}

Berdasarkan latar belakang yang telah diuraikan, maka rumusan masalah dalam penelitian ini adalah sebagai berikut:

1. Apakah kepemilikan manajerial berpengaruh positif terhadap kebijakan dividen?

2. Apakah cash ratio berpengaruh positif terhadap kebijakan dividen?

3. Apakah debt to equity ratio berpengaruh negatif terhadap kebijakan dividen?

4. Apakah growth opportunity berpengaruh negatif terhadap kebijakan dividen? 


\section{Tujuan Penelitian}

Berdasarkan rumusan masalah di atas, tujuan dilakukannya penelitian ini adalah:

1. Untuk membuktikan secara empiris bahwa kepemilikan manjerial berpengaruh positifterhadap kebijakan dividen.

2. Untuk membuktikan secara empiris bahwa cash ratio berpengaruh positif terhadap kebijakan dividen.

3. Untuk membuktikan secara empiris bahwa debt to equity ratio berpengaruh negatifterhadap kebijakan dividen.

4. Untuk membuktikan secara empiris bahwa growth opportunity berpengaruh negatifterhadap kebijakan dividen.

\section{B. LANDASAN TEORI DAN PENGEMBANGAN HIPOTESIS}

\section{Landasan Teori}

Hubungan keagenan menurut Jensen and Meckling (1976) adalah suatu hubungan yang terjadi karena adanya kontrak antara pemilik perusahaan (principal) dengan seseorang/manajer (agent) untuk menjalankan beberapa pekerjaan sesuai dengan keinginan pemilik perusahaan. Manajer selaku agen dari pemilik perusahaan, terkadang membuat keputusan yang tidak optimal dan bertentangan dengan kepentingan pemilik (Jensen and Meckling, 1976). Perbedaan kepentingan ini yang akhirnya membuat konflik kepentingan yang disebut dengan masalah keagenan (agency problem). Kebijakan dividen yang dilakukan oleh perusahaan (manajer) berkaitan dengan teori agensi karena pada dasarnya teori agensi menjelaskan konflik kepentingan. Dalam hal ini konflik kepentingan yang terjadi antara investor dengan manajer. Investor menginginkan setiap tahunnya mendapatkan pembagian dividen dari laba yang diperoleh perusahaan. Sedangkan manajer akan membagikan dividen setelah perusahan membayar kewajibannya berupa hutang pada kreditor. Selain itu manajer juga akan mempertimbangkan apakah akan membayar dividen atau menjadikan laba ditahan atas laba yang diperoleh untuk pendanaan perusahaan.

Kebijakan deviden merupakan bagian yang menyatu dengan keputusan pendanaan perusahaan. Rasio pembayaran deviden menentukan jumlah laba yang ditahan sebagai sumber pendanaan. Semakin besar laba ditahan semakin sedikit jumlah laba yang dialokasikan untuk pembayaran deviden. Alokasi penentuan laba sebagai laba ditahan dan pembayaran deviden merupakan aspek utama dalam kebijakan deviden (Wachowicz,1997).

Kebijakan deviden bersangkutan dengan penentuan pembagian pendapatan (earning) antara pengunaan pendapatan untuk dibayarkan kepada para pemegang saham sebagai deviden atau untuk digunakan didalam perusahaan, yang berarti laba tersebut harus ditahan didalam perusahaan.Dasar pengukuran kebijakan dividen dalam penelitian ini menggunakan Dividend Payout Ratio (DPR). Dividend payout ratio menentukan jumlah laba yang dibagi dalam bentuk dividen kas dan laba yang ditahan sebagai sumber pendanaan (Meilani dan Amboningtyas, 2017). Dividend payout ratio adalah persentase dari pendapatan yang akan dibayarkan kepada pemegang saham sebagai “cash dividend". Dividend payout ratio adalah perbandingan antara dividend per share dengan earning per share pada periode yang bersangkutan. Di dalam komponen dividend per share terkandung unsur dividen, sehingga apabila semakin besar dividend yang dibagikan maka semakin besar pula dividend payout rationya. Pembagian dividend yang besar 
bukanya tidak diinginkan oleh investor, tetapi jika dividend payout ratio lebih besar dari $25 \%$ dikuatirkan akan menyebabkan kesulitan likuiditas keuangan perusahaan dimasa mendatang.

\section{Pengembangan Hipotesis}

\section{Kepemilikan manajerialberpengaruh positif terhadap dividend payout ratio}

Wahidahwati (2002) dalam Wijayanto dan Putri (2018) mendefinisikan kepemilikan manajerial sebagai tingkat kepemilikan saham pihak manajemen yang secara aktif ikut dalam pengambilan keputusan, misalnya direktur, manajemen, dan komisaris. Manajer mendapat kesempatan untuk terlibat dalam kepemilikan saham dengan tujuan untuk mensetarakan dengan para pemegang saham. Pendekatan keagenan menganggap stuktur kepemilikan manajerial sebagai suatu instrumen atau alat yang digunakan untuk mengurangi konflik keagenan di suatu perusahaan (Jensen dan Meckling, 1976). Meningkatkan kepemilikan manajerial merupakan salah satu cara untuk mengatasi masalah yang ada di perusahaan tersebut. Meningkatnya kepemilikan manajerial maka kepentingan pemegang saham dan manajer pun menjadi sejajar dan akan mengurangi agency cost yang timbul karena biaya pengawasan dalam perusahaan. Meningkatnya kepemilikan manajerial juga akan membuat manajer termotivasi untuk meningkatkan kinerjanya sehingga akan berdampak baik kepada perusahaan serta dapat memenuhi keinginan para pemegang saham.

Hasil penelitian yang telah dilakukan sebelumnya memberikan hasil yang berbeda-beda mengenai pengaruh kepemilikan manajerial terhadap kebijakan perusahaan dalam membayarkan dividen. Penelitian yang dilakukan oleh Dewi (2008) yang menghasilkan kepemilikan manjerial berpengaruh negatif terhadap dividend payout ratio. Hal ini menjelaskan bahwa, apabila tingkat kepemilikan manajerial tinggi maka perusahaan cenderung akan mengalokasikan laba pada laba ditahan daripada membayarkan dividen dengan alasan sumber dana internal lebih efisien dibandingkan sumber dana eksternal. Sedangkan hasil penelitian lainnya memberikan hasil berbeda yang dilakukan oleh Nuringsih (2005), Awalina (2016), Yusuf dan Rahmawati (2016), dan Prihatini, Rahmiat dan Susanti (2018) hasil penelitian menunjukkan kepemilikan manjerial berpengaruh positif dan signifikan terhadap dividend payout ratio. Berdasarkan uraian tersebut, hipotesis dalam penelitian ini merujuk pada penelitian Nuringsih (2005), Awalina (2016), Yusuf dan Rahmawati (2016), dan Prihatini, Rahmiat dan Susanti (2018).

\section{Cash ratio berpengaruh positif terhadap dividend payout ratio}

Rasio kas (cash ratio) menurut Kasmir (2012) adalah rasio kas atau (cash ratio) merupakan alat yang digunakan untuk mengukur seberapa besar uang kas yangtersedia untuk membayar utang. Hasil dari penelitian-penelitian sebelumnya memberikan hasil yang berbeda-beda. Dalam penelitian yang dilakukan oleh Pasaribu, dkk (2014) menunjukkan bahwa pengaruh cash ratio terhadap dividend payout ratio berpengaruh negatif dan sigifikan. Sedangkan penelitian yang dilakukan oleh Susmiandini dan Khoirotunnisa (2017) menunjukkan cash ratio berpengaruh positif dan signifikan terhadap dividend payout ratio.

Berdasarkan uraian tersebut hipotesis dalam penelitian ini merujuk pada penelitian Susmiandini dan Khoirotunnisa (2017). Hal ini karena cash ratio digunakan untuk mengetahui kemampuan perusahaan dalam membayar kewajiban jangka pendeknya yang harus segera dipenuhi dari kas yang tersedia dalam perusahaan dan setara kas yang dapat diuangkan secara cepat. Semakin tinggi cash ratio pada perusahaan menunjukkan kemampuan perusahaan dalam membayar kewajiban jangka pendeknya semakin besar dilihat 
dari kas dan setara kas yang dimiliki. Dan hal ini berkaitan dengan cash ratio dimana semakin kuat posisi kas dan setara kas yang dimiliki suatu perusahaan maka semakin besar pula kemampuan perusahaan dalam membayar dividen.

\section{Debt to equity ratio berpengaruh negatif terhadap dividend payout ratio}

Penelitian ini menggunakan debt to equity ratio sebagai proksi dari leverage. Rasio ini menunjukkan seberapa besar aset perusahaan didanai oleh hutang atau modal yang dimiliki perusahaan.Penelitian yangdilakukan oleh Huyen (2015) yang menunjukkan debt to equity ratio berpengaruh negatifsignifikan terhadap dividend payout ratio. Selain itu hasil yang sama juga diperoleh penelitian sebelumnya yaitu oleh Yasa dan Wirawati (2016), Simbolon dan Sampurno (2017), dan Meilani dan Amboningtyas (2017). Hasil penelitian berbeda dihasilkan oleh Deitana (2009) dan Arilaha (2009) yang menghasilkan bahwa debt to equity ratio tidak berpengaruh terhadap dividend payout ratio.

Berdasarkan uraian tersebut, hipotesis dalam penelitian ini merujuk pada penelitian Huyen (2015), Yasa dan Wirawati (2016), Simbolon dan Sampurno (2017), dan Meilani dan Amboningtyas (2017).Debt to

equity ratio menunjukkan proporsi relatif antara hutang dan ekuitas yang digunakan untuk membiayai aset perusahaan (Meilani dan Amboningtyas, 2017). Jika nilai debt to equity ratio tinggi, hal ini berarti bahwa perusahaan dibiayai oleh kreditor (pemberi hutang) dan bukan dari sumber keuangannya sendiri (investor). Sehingga perusahaan dalam membayar dividen bagi pemegang saham semakin kecil.

\section{Growth opportunity berpengaruh negatif terhadap dividend payout ratio}

Growth Opportunity perusahaan akan mempengaruhi besarnya dividen yang dibayarkan perusahaan. Besarnya growth opportunity sebuah perusahaan, akan berpengaruh pada jumlah dana yangdibutuhkan untuk investasi. Jika perusahaan lebih memfokuskan pada pertumbuhan perusahaan, maka kebutuhan dana pun akan semakin tinggi yang memaksa manajemen menahankeuntungan dan berdampak pada rendahnya dividen (Pribadi dan Sampurno, 2012).

Pribadi dan Sampurno (2012) menghasilkan growth opportunity berpengaruh negatif namun tidak signifikan terhadap dividend payout ratio. Sedangkan penelitian lainnya yang dilakukan oleh Simbolon dan Sampurno (2017) growth opportunity yang diproksikan sebagai asset growth berpengaruh negatif signifikan terhadap dividend payout ratio.Perusahaan-perusahaan yang mengalami pertumbuhan yang cepat harus meningkatkan aset yang dimiliki. Dengan demikian, perusahaan dengan tingkat pertumbuhan yang tinggi akan membutuhkan dana yang lebih besar di masa depan sehingga akan banyak menahan laba untuk menunjang pertumbuhan perusahaan. Sehinggasemakin tinggi tingkat pertumbuhan suatu perusahaan maka semakin banyak danayang dibutuhkan oleh perusahaan untuk mengembangkan perusahaannya sehingga perusahaan akan dividen yang dibayarkan perusahaan semakin kecil.

\section{METODE PENELITIAN}

\section{Populasi dan Sampel}

Populasi pada penelitian ini adalah perusahaan yang terdaftar di Bursa Efek Indonesia (BEI) pada tahun 2013-2017.Sampel dipilih dari populasi perusahaan yang sahamnya terdaftar dan diperdagangkan di Bursa Efek Indonesia mulai tahun 2013-2017 yaitu perusahaan manufaktur. Pemilihan sampel ini dilakukan 
dengan cara purposive judgement sampling yang merupakan bagian dari metode non-probability sampling, yaitu pemilihan sampel secara tidak acak dengan kriteria-kriteria tertentu.

\section{Pengumpulan dan Analisis Data}

Penelitian ini menggunakan data sekunder yang berasal dari laporan tahunan atau laporan keuangan tahunan perusahaan manufaktur yang terdaftar di BEI periode 2013-2017. Data sekunder dalam penelitian ini adalah laporan keuangan perusahaan non-keuangan yang terdaftar di BEI yang berupa laporan keuangan perusahaan yang dipublikasikan pada tahun 2013-2017. Data diperoleh dari mengakses situs di BEI yaitu www.idx.co.id dan website resmi perusahaan.

\section{Definisi dan Pengukuran Operasional Variabel}

\section{Variabel Dependen}

Variabel dependen dalam penelitian ini adalah dividend payout ratio. Dividend payout ratio merupakan presentase dari pendapatan yang akan dibayarkan kepada pemegang saham dalam bentuk dividen tunai, artinya besar kecilnya dividend payout ratio akan mempengaruhi keputusan investasi para pemegang saham di sisi lain berpengaruh pada kondisi keuangan perusahaan. Dividend payout ratio dapat diukur dengan menggunakan konsep dividen yang sama yang dibayarkan dibagi dengan pendapatan, atau laba bersih (Myers and Bacon, 2002).

$$
D P R=\frac{\text { Dividends Per Share }}{\text { Earnings Per Share }} \times 100 \%
$$

\section{Variabel Independen}

\section{1). Kepemilikan Manajerial}

Wahidahwati (2002) dalam Wijayanto dan Putri (2018) mendefinisikan kepemilikan manajerial sebagai tingkat kepemilikan saham pihak manajemen yang secara aktif ikut dalam pengambilan keputusan, misalnya direktur, manajemen, dan komisaris.Besar kecilnya jumlah kepemilikan saham manajerial dalam perusahaan mengindikasikan adanya kesamaan kepentingan antara manajer dengan pemegang saham. Menurut Sari dan Budiasih (2016) pengukuran kepemilikan manajerial dirumuskan sebagai berikut:

$$
\mathrm{KM}=\frac{\text { JumlahSahamKomisaris, Direksi, Manajemen }}{\text { JumlahSahamBeredar }} \times 100 \%
$$

\section{2). Cash Ratio}

Cash Ratio (CR) adalah salah satu rasio likuiditas yang bertujuan untuk mengukur kemampuan suatu perusahaan dalam memenuhi kewajiban jangka pendeknya dengan aset lancarnya (current assets). Rasio ini dapat dirumuskan sebagai berikut (Brigham, 2005):

$$
\text { Cash Ratio }=\frac{\text { Cash }+ \text { Cash Equivalent }}{\text { Current Liability }} \times 100 \%
$$

\section{3). Debt To Equity Ratio}

Debt to equity ratio sebagai proksi dari leverage. Debt to Equity Ratio (DER) yaitu rasio hutang pada 
modal. Rasio ini menilai seberapa jauh perusahaan dibiayai oleh hutang, dimana semakin besar nilai rasio ini menunjukkan gejala yang kurang baik bagi perusahaan serta kemungkinan pembayaran dividen rendah (Sartono, 2001).

Debt to Equity Ratio (DER) diukur melalui perbandingan antara total hutang dengan ekuitas perusahaan. Rumus dari Debt to Equity Ratio (DER) ialah (Ang, 1997):

$$
\text { DebttoEquityRatio }=\frac{\text { TotalLiabilities }}{\text { TotalEquity }} \times 100 \%
$$

\section{4). Growth Opportunity}

Pengertian pertumbuhan dalam manajemen keuangan pada umumnya menunjukkan peningkatan ukuran skala perusahaan. Growth Opportunit (kesempatan bertumbuh) sesuai dengan penelitian Simbolon dan Sampurmo (2017), Mas'ud (2008) dalam Andika (2017) dan Huang (2005) dalam Erfiana dan Ardiansari (2016) mernproksikan growth opportunity dengan asset growth yangmenunjukkan besarnya atas kenaikan danpenurunan (pertumbuhan) aktivasetiap tahun. Rasio ini mencerminkan perbandingan antara pertumbuhan aset tahun sekarang dengan aset tahun lalu.

Growth Opportunity diukur berdasarkan asset growth:

$$
\text { AssetGrowth }=\frac{\text { AsetTahunt }- \text { AsetTahunt }-1}{\text { AsetTahunt }-1}
$$

\section{Variabel Kontrol}

Variabel kontrol merupakan variabel yang digunakan untuk melengkapi atau mengontrol hubungan kausal antara variabel independen dan variabel dependen, agar mendapatkan model empiris yang lebih lengkap dan lebih baik. Variabel kontrol adalah variabel yang dikendalikan atau dibuat konstan sehingga hubungan variabel bebas terhadap variabel terikat tidak dipengaruhi oleh faktor luar yang tidak diteliti.

\section{1). Profitability}

Fahmi (2015) menyatakan bahwa profitability merupakan rasio yang mengukur efektifitas manajemen secara keseluruhn yang ditujukan oleh besar kecilnya tingkat keuntungan yang diperoleh dalam hubungannya dengan penjualan maupun investasi.Merujuk pada penelitian Myers dan Bacon (2002) return on equity (ROE) dapat dirumuskan sebagai berikut:

$$
\text { ReturnOnEquity }=\frac{\text { LabaBersihSetelahPajak }}{\text { TotalEkuitas }}
$$

\section{Metode Analisis Data}

Analisi data digunakan dengan analisis statistik deskriptif, uji asumsi klasik dengan uji normalitas, uji multikolonearitas, uji heterokedastisitas dan uji autokorelasi.

\section{ANALISIS DAN PEMBAHASAN}

\section{Pemilihan Sampel}


Penelitian ini menggunakan perusahaan non-keuangan yang terdaftar di Bursa Efek Indonesia (BEI) dari tahun 2013-2017 sebagai sampel. Penulis memperoleh 465 perusahaan yang terdaftar selama tahun observasi dan hanya 150 perusahaan yang memenuhi kriteria yang telah ditentukan. Penelitian ini menggunakan metode purposive judgement sampling dengan rincian sebagai berikut:

\section{Tabel 1 Proses Pengambilan Sampel Penelitian}

\begin{tabular}{lc}
\hline \multicolumn{1}{c}{ Keterangan } & Jumlah \\
\hline Perusahaan non-keuangan yang terdaftar di Bursa Efek Indonesia (BEI) dari tahun 2013-2017 & 465 \\
Perusahaan yang listing pada tahun penelitian & $(97)$ \\
Perusahaan yang mengalami kerugian selama tahun penelitian 2013-2017 & $(198)$ \\
Perusahaan yang delisting dari BEI & $(20)$ \\
Perusahaan yang menjadi sampel penelitian & 150 \\
Tahun penelitian & 5 \\
Jumlah sampel & 750 \\
\hline
\end{tabular}

Sumber: Data sekunder diolah, 2020.

\section{Analisis Data dan Pembahasan}

\section{Statistik Deskriptif}

Statistik deskriptif memberikan gambaran atau deskripsi data dari 150 perusahaan yang menjadi sampel penelitian melalui nilai minimum, nilai maksimum, nilai rata-rata (mean), dan standar deviasi.

\section{Tabel 2 Tabel Statistik Deskriptif}

\begin{tabular}{cccccc}
\hline & \multicolumn{2}{c}{ Descriptive Statistics } & \\
& $\mathrm{N}$ & Minimum & Maximum & Mean & Std. Deviation \\
\hline KM & 502 &, 0000 &, 3732 &, 019338 &, 0561669 \\
CR & 502 &, 0063 & 1,9531 &, 480640 &, 4619634 \\
DER & 502 &, 0077 & 1,9949 &, 816929 &, 4571302 \\
GO & 502 &,- 1598 & 1,2367 &, 121140 &, 1424629 \\
ROE & 502 &, 0004 & 1,2415 &, 122159 &, 0938978 \\
DPR & 502 &, 0000 & 1,2371 &, 238821 &, 2244005 \\
Valid N (listwise) & 502 & & & & \\
\hline
\end{tabular}

Sumber: Data Olahan SPSS 25, 2020.

\section{Uji Normalitas}

Pada penelitian ini uji normalitas yang digunakan adalah dengan melihat grafik normal probability plot. Pada prinsipnya normalitas dapat dideteksi dengan melihat penyebaran data (titik) pada sumbu diagonal dari grafik $P$-P Plot.

Gambar 1 Hasil Uji statistik grafik normal probability plot Sebelum Data Transform

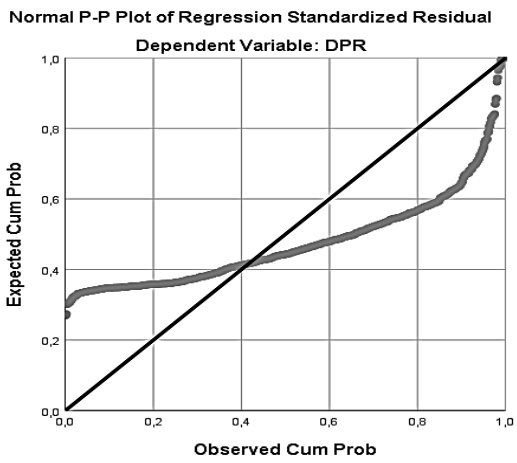

Sumber: Data Olahan SPSS 25, 2020.

Gambar 2 Hasil Uji statistik grafik normal probability plot Sesudah Data Transform 


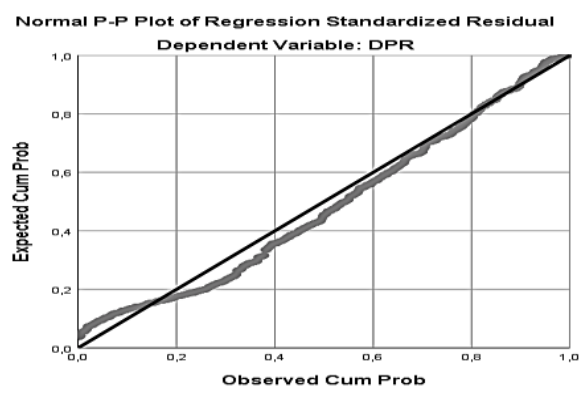

Sumber: Data Olahan SPSS 25, 2020.

Pada Gambar 1 menjelaskan bahwa titik-titik menyebar danmenjauh dari arah garis diagonal. Hal ini mengindikasi bahwa variabel-variabel dalam model regresi tidak terdistribusi secara normal. Sedangkan Gambar 2 diatas terlihat $P$-P plots yang menunjukan bahwa titik-titik menyebar disekitar garis diagonal danmengikuti arah garis diagonal. Hal ini mengindikasi bahwa variabel-variabel dalam model regresi terdistribusi secara normal.

\section{Uji Multikolinearitas}

Uji multikolinearitas bertujuan untuk menguji apakah dalam model regresi ditemukan adanya korelasi antar variabel independen (Ghozali, 2016).

Tabel 3 Hasil Uji Multikolinearitas

(Tidak Ada Variabel Kontrol)

\begin{tabular}{llll}
\hline Model & & \multicolumn{2}{c}{ Collinearity Statistics } \\
& & Tolerance & VIF \\
\hline 1 & (Constant) &, 995 & 1,005 \\
& KM &, 790 & 1,265 \\
& CR &, 765 & 1,308 \\
& DER &, 946 & 1,057 \\
\hline
\end{tabular}

Sumber: Data diolah SPSS 25, 2020.

Tabel 4 Hasil Uji Multikolinearitas (Ada Variabel Kontrol)

\begin{tabular}{|c|c|c|c|}
\hline \multirow{2}{*}{\multicolumn{2}{|c|}{ Model }} & \multicolumn{2}{|c|}{ Collinearity Statistics } \\
\hline & & Tolerance & VIF \\
\hline \multirow[t]{6}{*}{1} & (Constant) & & \\
\hline & KM & ,995 & 1,005 \\
\hline & $\mathrm{CR}$ &, 770 & 1,299 \\
\hline & DER & ,763 & 1,311 \\
\hline & $\mathrm{GO}$ &, 891 & 1,122 \\
\hline & ROE & ,902 & 1,108 \\
\hline
\end{tabular}

Sumber: Data diolah SPSS 25, 2020.

Berdasarkan hasil uji multikolinearitas pada tabel di atas menunjukkan bahwa tidak ada variabel bebas yang digunakan dalam penelitian memiliki nilai tolerance $\leq 0,10$ atau sama dengan nilai $\mathrm{VIF} \geq 0,10$ yang artinya model regresi dalam penelitian ini tidak mengalami multikolinearitas dan model regresi layak untuk digunakan.

\section{Uji Heterokedastisitas}

Uji heteroskedatisitas bertujuan untuk menguji apakah dalam model regresi terjadi ketidaksamaan variance dari residual satu pengamatan kepengamatan yang lain (Ghozali, 2016).

\section{Gambar 3 Hasil Uji Heteroskedastisitas}




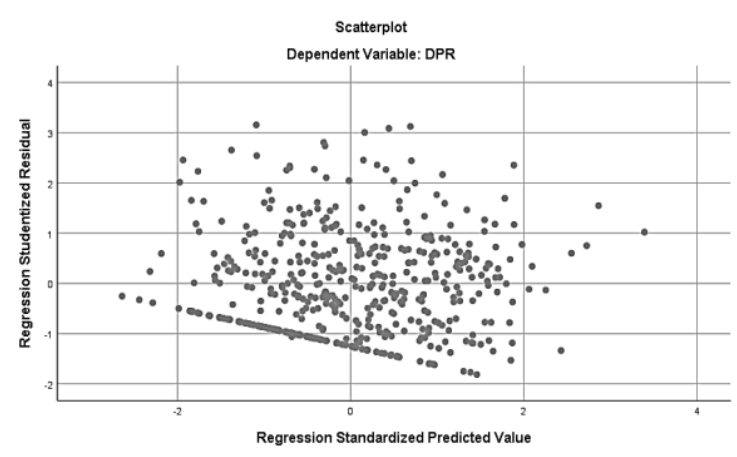

Sumber: Data diolah SPSS 25, 2020

Berdasarkan Gambar 3 terlihat titik-titik menyebar secara acak baik di atas maupun dibawah angka 0 pada sumbu Y, dan juga terlihat titik-titik tersebut membentuk suatu pola tertentu. Dengan demikian dapat disimpulkan bahwa penelitian ini terbebas dari masalah heteroskedastisitas.

\section{Uji Autokorelasi}

Uji autokorelasi bertujuan untuk menguji apakah dalam model regresi linear ada korelasi yang terjadi antara kesalahan pengganggu pada periode $\mathrm{t}$ dengan kesalahan pengganggu pada periode $\mathrm{t}-1$ (sebelumnya) (Ghozali, 2016).Model dikatakan tidak terdapat autokorelasi apabila nilai signifikansi Run Test > 0,05.Hasil uji Rrun Test pada penelitian ini dapat dilihat pada tabel dibawah ini:

\section{Table 5 Hasil Uji Autokorelasi}

(Tidak Ada Variabel Kontrol)

\begin{tabular}{lll}
\hline & Runs Test & \\
& & Unstandardized Residual \\
\hline Asymp. Sig. (2-tailed) &, 670 \\
a. Median & \\
\hline Sumber: Data Diolah SPSS 25, 2020.
\end{tabular}

Table 6 Hasil Uji Autokorelasi

(Ada Variabel Kontrol)

\begin{tabular}{lll}
\hline & Runs Test & \\
& & Unstandardized Residual \\
\hline Asymp. Sig. (2-tailed) & &, 670 \\
a. Median & & \\
\hline Sumber: Data Diolah SPSS 25, 2020. &
\end{tabular}

Berdasarkan hasil uji Run Testsebelum dan sesudah adanya varibel kontrol nilai Asymp. Sig. (1tailed) sebesar 0,670>0,05 yang artinya model regresi dalam penelitian ini tidak mengalami autokorelasi dan model regresi layak untuk digunakan.

\section{Analisis Regresi}

Penggunaanregresi linier berganda untuk mengukur kekuatan hubungan antara dua variabel atau lebih dan juga menunjukan arah hubungan antara variabel dependen dan variabel independen sehingga dapat membedakan kedua variabel dalam penelitian (Ghozali, 2016). Adapun hasil pengolahan data sebagai berikut: 


\begin{tabular}{|c|c|c|c|}
\hline & \multirow[t]{2}{*}{ Model } & \multicolumn{2}{|c|}{ Unstandardized Coefficients } \\
\hline & & $\mathrm{B}$ & Std. Error \\
\hline \multirow[t]{5}{*}{1} & $\mathrm{C}$ & ,217 & ,028 \\
\hline & KM & ,419 &, 587 \\
\hline & $\mathrm{CR}$ & 089 & ,032 \\
\hline & DER &,- 074 &, 032 \\
\hline & GO &,- 041 & ,089 \\
\hline
\end{tabular}

Sumber: Data Diolah SPSS 25, 2020.

Berdasarkan hasil pengujian dengan metode regresi linier berganda untuk menguji pengaruh variabel-variabel independen (KM, CR, DER, dan GO) terhadap variabel dependen (DPR) maka dapat disusun sebuah persamaan sebagai berikut :

\section{DPR= 0,217+0,089CR-0,074DER+e}

Persamaan tersebut menjelaskan bahwa rata-rata perusahaan membagikan dividen berupa dividend payout ratio sebesar 0,217 dengan asumsi bahwa variabel yang mempengaruhi tidak mengalami perubahan (konstan). Dalam persamaan regresi di atas dapat disimpulkan bahwa hanya dua variabel independen yang dapat mempengaruhi secara signifikan yaitu variabel cash ratio dan variabel debt to equity ratio.

\begin{tabular}{|c|c|c|c|}
\hline \multicolumn{4}{|c|}{$\begin{array}{l}\text { Tabel } 8 \text { Hasil Analisis Regresi } \\
\text { (Ada Variabel Kontrol) }\end{array}$} \\
\hline \multirow{2}{*}{\multicolumn{2}{|c|}{ Model }} & \multicolumn{2}{|c|}{ Unstandardized Coefficients } \\
\hline & & $\mathrm{B}$ & Std. Error \\
\hline \multirow[t]{6}{*}{1} & $\mathrm{C}$ &, 168 &, 029 \\
\hline & KM & ,438 &, 576 \\
\hline & $\mathrm{CR}$ & ,066 & 032 \\
\hline & DER &,- 068 & 031 \\
\hline & GO &,- 135 & 089 \\
\hline & ROE &, 554 &, 126 \\
\hline
\end{tabular}

Berdasarkan hasil pengujian dengan metode regresi linier berganda untuk menguji pengaruh variabel-variabel independen (KM, CR, DER, dan GO) serta variabel kontrol (ROE) terhadap variabel dependen (DPR) maka dapat disusun sebuah persamaan sebagai berikut :

\section{$\mathrm{DPR}=0,168+0,066 \mathrm{CR}-0,068 \mathrm{DE}-0,135 \mathrm{GO}+0,554 \mathrm{ROE}+\mathrm{e}$}

Persamaan regresi di atas menjelaskan bahwa setelah adanya variabel kontrol nilai konstanta menurun menjadi 0,168 dan koefisien beta yang mempengaruhi variabel dependen dari hasil uji regresi mengalami perubahan. Hal ini dapat disebabkan karena setelah adanya varibel kontrol yang memberikan batasan pada variabel yang dapat mempengaruhi variabel dependen yaitu variabel dividend payout ratio diluar variabel independen dalam penelitian ini. Dan variabel kontrol memiliki koefisien beta 0,554 , hal ini menunjukkan bahwa variabel kontrol mampu memberikan pengendalian dan batasan pada variabel diluar penelitian yang mempengaruhi variabel dependen selain variabel yag diteliti dalam penelitian ini. Selain itu, variabel kontrol memberikan pengaruh signifikan terhadap variabel dividend payout ratio.

\section{Pengujian Hipotesis}

Menurut Ghozali (2016), ketepatan fungsi regresi dalam menaksir nilai actual dapat diukur dari 
goodness of fit-nya. Secara statistik dapat diukur dari nilai koefisien determinasi, nilai statistik F, dan nilai statistik t.

\section{1) Uji Kelayakan Model Regresi (Uji F)}

Pengujian hipotesis uji $\mathrm{F}$ digunakan untuk melihat apakah secara keseluruhan variabel bebas mempunyai pengaruh yang bermakna terhadap variabel terikat (Ghozali, 2016). Dari hasil pengujian simultan diperoleh sebagai berikut:

Tabel 9Kelayakan Model Regresi (Uji F)

(Tidak Ada Variabel Kontrol)

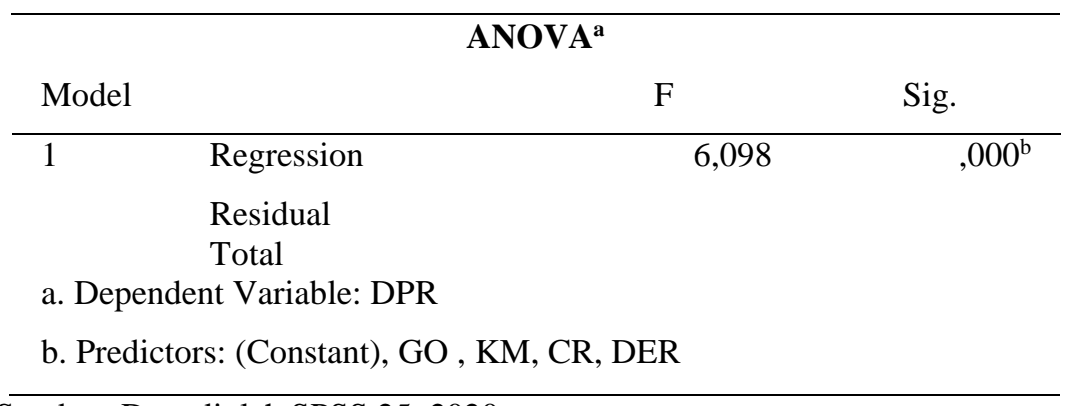

Sumber: Data diolah SPSS 25, 2020.

Hasil pengolahan data terlihat bahwa variabel independen (KM, CR, DER, GO) mempunyai signifikansi F hitung sebesar 0,000 lebih kecil dari tingkat signifikansi 0,05. Dengan demikian hasil analisis dalam penelitian ini menunjukkan bahwa secara bersama-sama dan signifikan variabel independen (KM, CR, DER, GO) memberikan pengaruh terhadap kebijakan deviden.

Tabel 10 Kelayakan Model Regresi (Uji F)

(Ada Variabel Kontrol)

\begin{tabular}{|c|c|c|c|}
\hline \multicolumn{4}{|c|}{ ANOVA $^{\mathrm{a}}$} \\
\hline \multicolumn{2}{|c|}{ Model } & $\mathrm{F}$ & Sig. \\
\hline 1 & Regression & 8,916 &, $000^{\mathrm{b}}$ \\
\hline & \multicolumn{3}{|l|}{ Residual } \\
\hline & \multicolumn{3}{|l|}{ Total } \\
\hline \multicolumn{4}{|c|}{ a. Dependent Variable: DPR } \\
\hline \multicolumn{4}{|c|}{ b. Predictors: (Constant), ROE, KM, DER, GO, CR } \\
\hline
\end{tabular}

Sumber: Data diolah SPSS 25, 2020.

Hasil pengolahan data terlihat bahwa variabel independen (KM, CR, DER, GO) dan variabel kontrol (ROE) mempunyai nilai $\mathrm{F}$ sebesar 8,916 dari sebelum adanya variabel kontrol hanya sebesar 6,098. Hal ini menjelaskan bahwa varibel kontrol memberikan pengaruh yang lebih besar untuk mempengaruhi secara simultan terhadap variabel dependen yaitu kebijakan dividen. Dengan nilai signifikan $0,000 \leq 0,05$. Dengan demikian hasil analisis dalam penelitian ini menunjukkan bahwa secara bersama-sama dan signifikan variabel independen (KM, CR, DER, GO) dan variabel kontrol (ROE) 
memberikan pengaruh terhadap kebijakan deviden.

\section{2) Uji Koefisien Determinasi $\left(\mathbf{R}^{2}\right)$}

Koefisien determinasi (Adjusted $\mathrm{R}^{2}$ ) digunakan untuk mengukur seberapa jauh kemampuan model dalam menerangkan variasi dari variabel dependen. Nilai $\mathrm{R}^{2}$ yang mendekati satu menunjukkan variabel-variabel independen memberikan hampir semua informasi yang dibutuhkan untuk memperbaiki variabel dependen (Ghozali, 2016).

\section{Tabel 11 Hasil Uji Determinasi}

(Tidak Ada Variabel Kontrol)

\begin{tabular}{lcc}
\hline \multicolumn{2}{c}{ Model Summary $^{\text {b }}$} & \\
Model & R Square & Adjusted R Square \\
\hline 1 &, 052 & \\
a. Predictors: (Constant), GO , KM, CR, DER & \\
b. Dependent Variable: DPR & \\
Sumber: Data diolah SPSS 25, 2020.
\end{tabular}

Berdasarkan hasil penelitian ini menunjukkan bahwa nilai koefisien determinan $\left(\mathrm{R}^{2}\right)$ diperoleh sebelum adanya variabel kontrol sebesar 0,044 atau 4,4\%. Hal ini menunjukkan bahwa 4,4\% dividend payout ratio (DPR) dipengaruhi oleh variabel KM, CR, DER,dan GO. Dan sisanya 95,6 \% dipengaruhi variabel lain di luar variabel independen yang diteliti.

Tabel 12 Hasil Uji Determinasi

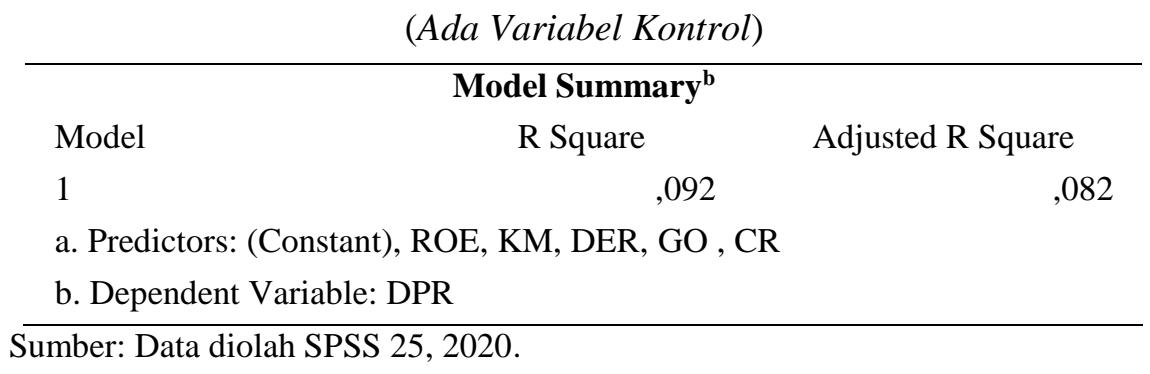

Sedangkan nilai koefisien determinan $\left(\mathrm{R}^{2}\right)$ diperoleh setelah adanya variabel kontrolsebesar 0,082 atau $8,2 \%$. Hal ini menunjukkan bahwa 8,2\% dividend payout ratio (DPR) dipengaruhi oleh variabel KM, CR, DER, GO dan ROE. Sedangkan sisanya 91,8\% terdapat faktor-faktor lain yang dapat mempengaruhi dividend payout ratiodan tidak dapat dijelaskan oleh variabel independen dalam penelitian ini. Perubahan besarnya nilai koefisien determinan $\left(\mathrm{R}^{2}\right)$ disebabkan karena variabel kontrol mampu membatasi dan mengendalikan variabel atau faktor lain di luar variabel independen yang sedang diteliti untuk mempengaruhi variabel dependen yaitu kebijakan dividen.

\section{3) Uji Signifikan Parameter Individual (Uji-t)}

Uji statistik t digunakan untuk mengetahui secara parsial pengaruh masing-masing variabel independen terhadap variabel dependen. Uji statistik t pada dasarnya menunjukkan seberapa jauh 
pengaruh satu variable penjelas/independen secara individual dalam menerangkan variasi variabel dependen. Pengujian dilakukan dengan menggunakan tingkat signifikansi 0,05 ( $\alpha=5 \%$ ) (Ghozali, 2016).

Tabel 13 Hasil Uji Signifikan Parameter Individual (Uji-t)

(Tidak Ada Variabel Kontrol)

\begin{tabular}{ccc}
\hline Model & T & Sig. \\
\hline C & 7,866 &, 000 \\
KM &, 713 &, 476 \\
CR & 2,729 &, 007 \\
DER & $-2,317$ &, 021 \\
GO &,- 461 &, 645 \\
\hline
\end{tabular}

Sumber: Data Diolah SPSS 25, 2020.

Tabel 14 Hasil Uji Signifikan Parameter Individual (Uji-t)

(Ada Variabel Kontrol)

\begin{tabular}{cccc}
\hline & Model & T & Sig. \\
\hline 1 & C & 5,722 &, 000 \\
& KM &, 761 &, 447 \\
& CR & 2,043 &, 042 \\
& DER & $-2,157$ &, 032 \\
& GO & $-1,511$ &, 002 \\
& ROE & 4,380 &, 000 \\
\hline
\end{tabular}

Sumber: Data Diolah SPSS 25, 2020.

Berdasarkan tabel14 hasil uji statistik t dapat dilihat tingkat signifikansi pengaruh variabel independen terhadap variabel dependen secara individual sebagai berikut:

1. Variabel independen kepemilikan manajerial memiliki t hitung sebesar 0,444 dengan nilai signifikansi sebesar 0,657. Nilai signifikansi kepemilikan manajerial sebesar 0,657>0,05 maka dapat disimpulkan bahwa kepemilikan manajerial berpengaruh positif tetapi tidak signifikan terhadap dividend payout ratio. Oleh karena itu, $\mathrm{H}_{1}$ yang menyatakan bahwa kepemilikan manajerial berpengaruh positif terhadap dividend payout ratio dinyatakan tidak terdukung.

2. Variabel independen cash ratio memiliki thitung sebesar 2,962 dengan nilai signifikansi sebesar 0,003. Nilai signifikansi cash ratio sebesar $0,003<0,05$ maka dapat disimpulkan bahwa cash ratio berpengaruh positif dan signifikan terhadap dividend payout ratio. Oleh karena itu, $\mathrm{H}_{2}$ yang menyatakan bahwa cash ratio berpengaruh positif terhadap dividend payout ratio dinyatakan terdukung.

3. Variabel debt to equity ratio manajerial memiliki t hitung sebesar $-2,447$ dengan nilai signifikansi sebesar 0,015. Nilai signifikansi debt to equity ratio sebesar 0,015<0,05 maka dapat disimpulkan bahwa debt to equity ratio berpengaruh negatif dan signifikan terhadap dividend payout ratio. Oleh karena itu, $\mathrm{H}_{3}$ yang menyatakan bahwa debt to equity ratio berpengaruh negatif terhadap dividend payout ratio dinyatakan terdukung.

4. Variabel independen growth opportunity memiliki t hitung sebesar -2,719 dengan nilai signifikansi sebesar 0,007. Nilai signifikansi growth opportunity sebesar 0,007<0,05 maka dapat disimpulkan bahwa growth opportunity berpengaruh negatif dan signifikan terhadap dividend payout ratio. Oleh karena itu, $\mathrm{H}_{4}$ yang menyatakan bahwa growth opportunity berpengaruh negatif terhadap dividend payout ratio dinyatakan terdukung. 
5. Variabel kontrol return on equity memiliiki t hitung sebesar 4,943 dengan nilai signifikansi sebesar 0,000. Dengan nilai signifikansi return on equity sebesar 0,000<0,05 maka dapat disimpulkan bahwa return on equity sebagai variabel kontrol berpengaruh positif dan signifikan terhadap dividend payout ratio. Oleh karena itu, $\mathrm{H}_{5}$ yang menyatakan bahwa return on equity berpegaruh positif terhadap dividend payout ratio dinyatakan terdukung.

\section{Pembahasan}

\section{Pengaruh Kepemilikan Manajerial Terhadap Dividend Payout Ratio}

Hasil pengujian hipotesis pada tabel 14 variabel independen kepemilikan manajerial menunjukkan arah positif dengan nilai koefisien beta 0,019 yang menunjukkan bahwa setiap peningkatan 1 kepemilikan manajerial akan meningkatkan kebijakan perusahaan dalam membagikan dividen berupa dividend payout ratio sebesar 0,019. Dan nilai signifikansi sebesar 0,657>0,05 sehingga dapat disimpulkan bahwa variabel independen kepemilikan manajerial berpengaruh positif tetapi tidak signifikan terhadap dividend payout ratio dan H1tidak terdukung. Artinya, besar kecilnya kepemilikan saham oleh manajerial tidak akan mempengaruhi besar kecilnya jumlah dividen yang akan dibagikan perusahaan. Hasil penelitian ini mendukung penelitian yang dilakukan oleh Wijayanto dan Putri (2018), Putri dan Irawati (2019), dan Wuisan, dkk. (2018).

Hasil ini sesuai dengan teori agency yang dijelaskan Jensen \& Meckling (1976) yang menyatakan bahwa semakin tinggi struktur kepemilikan yang dikuasai oleh manajemen atau semakin kecil yang dikuasai oleh pihak luar maka semakin berkurangnya agency problems. Hal ini karena semakin selarasnya antara kepentingan manajemen dengan kepentingan pemilik yang sebagian besar adalah manajemen sendiri. Meningkatnya kepemilikan manajerial yang juga merupakan salah satu mekanisme untuk mengurangi masalah keagenan berdasarkan agency theory yang membuat pembagian dividen sebagai mekanisme pengurang masalah keagenan menjadi berkurang.

\section{Pengaruh Cash Ratio Terhadap Dividend Payout Ratio}

Hasil pengujian hipotesis pada tabel 14 variabel independen cash ratio menunjukkan arah positif dengan nilai koefisien beta 0,144 yang menunjukkan bahwa setiap peningkatan 1 cash ratio akan meningkatkan kebijakan perusahaan dalam membagikan dividen berupa dividend payout ratio sebesar 0,144. Dan nilai signifikansi sebesar $0,003<0,05$ sehingga dapat disimpulkan bahwa variabel independen cash ratio berpengaruh positif dan signifikan terhadap dividend payout ratio dan H2terdukung. Artinya, besar kecilnya cash ratio akan mempengaruhi besar kecilnya jumlah dividen yang akan dibagikan perusahaan.

Hasil penelitian sejalan dengan penelitian yang dilakukan oleh Susmiandini dan Khoirotunnisa (2017) dan Putri, dkk. (2019) yang menunjukkan jika cash ratio berpengaruh positif dan signifikan terhadap dividend payout ratio. Cash ratio digunakan untuk mengetahui kemampuan perusahaan dalam membayar kewajiban jangka pendek yang harus dipenuhi dari kas dan setara kas yang tersedia di perusahaan. Semakin tinggi cash ratio yang dimiliki perusahaan maka hal ini menunjukkan kemampuan perusahaan dalam memenuhi kewajiban jangka pendeknya semakin besar dilihat dari kas dan setara kas yang dimiliki. Sehingga semakin kuat posisi cash ratio yang dimiliki perusahaan maka semakin besar pula kemampuan perusahaan dalam membayar dividen. 
Semakin likuid suatu perusahaan maka akan semakin besar kemungkinan perusahaan membayarkan kewajiban jangka pendek pada kreditor. Dan dari statistik deskriptif rata-rata perusahaan non keuangan yang terdaftar di BEI memiliki cash ratio sebesar 0,480640. Hal ini menjelaskan bahwa rata-rata perusahaan non keuangan yang terdaftar di BEI mempunyai tingkat likuiditas yag baik. Sehingga mampu untuk memenuhi kewajiban jangka pendeknya melalui kas dan setara kas yang tersedia. Dan kelebihaan dari kas dan setara kas yang telah digunakan tersebut dapat digunakan untuk membayarkan dividen pada para pemegang saham. Pembayaran dividen yang merupakan arus kas keluar sehingga free cash flow perusahaan lebih berfokus pada pembiayaan dividen untuk mengurangi masalah keagenan. Jika kas tersedia dengan baik untuk melunasi kewajiban, maka kelebihan kas tersebut dapat digunakan untuk membayarkan dividen pada pemegang saham.

\section{Pengaruh Debt to Equity Ratio Terhadap Dividend Payout Ratio}

Hasil pengujian hipotesis pada variabel independen debt to equity ratio menunjukkan arah positif dengan nilai koefisien beta $-0,118$ dan nilai signifikansi sebesar $0,015<0,05$ sehingga dapat disimpulkan bahwa variabel independen debt to equity ratio berpengaruh signifikan terhadap dividend payout ratio dan H3terdukung. Artinya, besar kecilnya debt to equity ratioyang dimiliki perusahaan akan mempengaruhi besar kecilnya jumlah dividen yang akan dibagikan perusahaan. Hasil penelitian mendukung penelitian yang dilakukan oleh Huyen (2015), Yasa dan Wirawati (2016), Simbolon dan Sampurno (2017), dan Meilani dan Amboningtyas (2017). Hasil penelitian menunjukkan debt to equity ratio berpengaruh negatifsignifikan terhadap dividend payout ratio.Hasil ini sesuai dengan agency theory yang menyatakan bahwa semakin tinggi leverage maka semakin rendah dividen yang akan dibagikan karena dividen dianggap berpotensi menguras dasar jaminan yang tersedia untuk debt holders dan berpotensi meningkatkan biaya utang (Hidayati dan Sunaryo, 2016).

\section{Pengaruh Growth Opportunity Terhadap Dividend Payout Ratio}

Hasil pengujian hipotesis pada tabel 14 variabel independen growth opportunity menunjukkan arah negatif dengan nilai koefisien beta -0,122yang menunjukkan bahwa setiap peningkatan 1 growth opportunityakan menurunkan kebijakan perusahaan dalam membagikan dividen berupa dividend payout ratio sebesar 0,122. Dan nilai signifikansi sebesar 0,007<0,05 sehingga dapat disimpulkan bahwa variabel independen growth opportunity berpengaruh negatif dan signifikan terhadap dividend payout ratio dan $\mathbf{H 4}$ terdukung. Artinya, semakin besar tingkat growth opportunity maka pembagian dividen untuk pemegang saham akan semakin kecil. Hal ini dikarenakan perusahaan dengan tingkat pertumbuhan yang tinggi akan membutuhkan dana yang lebih besar di masa depan sehingga akan banyak menahan laba untuk menunjang pertumbuhan perusahaan. Dan dari hasil penelitian menunjukkan bahwa rata-rata perusahaan non-keuangan memiliki tingkat growth opportunity sebesar 0,121140 setiap tahunnya dibandingkan dengan tahun sebelumnya. Sehingga semakin tinggi tingkat pertumbuhan suatu perusahaan maka semakin banyak danayang dibutuhkan oleh perusahaan untuk mengembangkan perusahaannya sehingga perusahaan akan dividen yang dibayarkan perusahaan semakin kecil. Hasil dari penelitian ini sejalan dengan penelitian yang dilakukan oleh Simbolon dan Sampurno (2017) yang menyatakangrowth opportunity yang diproksikan sebagaiasset growth berpengaruh negatif signifikan terhadap dividend payout ratio. 


\section{Pengaruh Return On Equity Terhadap Dividend Payout Ratio}

Hasil pengujian hipotesis pada varibel kontrol return on equity (ROE) menunjukkan arah positif dengan nilai koefisien beta 0,221 yang menunjukkan bahwa setiap peningkatan 1 return on equity (ROE) akan meningkatkan kebijakan perusahaan dalam membagikan dividen berupa dividend payout ratio (DPR) sebesar 0,221. Dan nilai signifikansi sebesar 0,000<0,05 sehingga dapat disimpulkan bahwa variabel kontrol return on equity (ROE) berpengaruh signifikan terhadap dividend payout ratio (DPR) dan $\mathrm{H5}$ terdukung. Artinya, besar kecilnya return on equity (ROE) akan mempengaruhi besar kecilnya jumlah dividen yang akan dibagikan perusahaan pada pemegang saham.

Hasil penelitian sejalan dengan penelitian yang dilakukan oleh Hastuti (2018), Sulaeman (2018) dan Astuti dan Muhamaddinah (2018). Hasil penelitian menunjukkan bahwa return on equity berpengaruh positif dan signifikan terhadap dividend payout ratio. Semakin tinggi rasio ini, maka semakin besar laba yang diperoleh perusahaan dari modal sendiri suatu perusahaan. Sehingga semakin besar pula kemungkinan perusahaan dalam membagikan dividen pada pemegang saham. Selain itu investor akan sangat tertarik dalam melihat profitabilitas perusahaan untuk berinvestasi dalam perusahaan tersebut.Selain itu, hasil dari penelitian ini mendukung agency theoryyang menyatakan bahwa profitabilitas merupakan salah satu penyebab terjadinya konflik kepentingan antara pemilik dan manajemen sehingga dalam mengatasinya maka dilakukannya pembagian dividen.

\section{E. SIMPULAN DAN SARAN}

\section{Kesimpulan}

1. Variabel independen kepemilikian manajerial (KM) tidak mempunyai pengaruh yang signifikan terhadap kebijaakan dividen yang diproksikan dividend payout ratio dengan nilai signifikan 0,447 dan nilai t hitung sebesar 0,761 . Hal ini berarti hipotesis dalam penelitian ini tidak terdukung.

2. Variabel independen cash ratio (CR) mempunyai pengaruh yang signifikan terhadap kebijaakan dividen yang diproksikan dividend payout ratio dengan nilai signifikan 0,042 dan nilai t hitung sebesar 2,043. Hal ini berarti hipotesis dalam penelitian ini terdukung.

3. Variabel independen debt to equity ratio (DER) mempunyai pengaruh yang signifikan terhadap kebijaakan dividen yang diproksikan dividend payout ratio dengan nilai signifikan 0,032 dan nilai $\mathrm{t}$ hitung sebesar -2,157. Hal ini berarti hipotesis dalam penelitian ini terdukung. Hal ini dikarenakan semakin tinggi debt to equity ratio (DER) maka semakin rendah dividen yang akan dibagikan karena dividen dianggap berpotensi menguras dasar jaminan yang tersedia untuk debt holders.

4. Variabel independen growth opportunity (GO) mempunyai pengaruh negatif yang signifikan terhadap kebijaakan dividen yang diproksikan dividend payout ratio dengan nilai signifikan 0,002 dan nilai $\mathrm{t}$ hitung sebesar -1,511. Hal ini berarti hipotesis dalam penelitian ini terdukung.

5. Variabel kontrol return on equity berpengaruh positif dan signifikan terhadap kebijaakan dividen yang diproksikan dividend payout ratio dengan nilai signifikan nilai signifikansi sebesar 0,000 dan thitung sebesar 4,380. Hal ini berarti, $\mathrm{H}_{5}$ yang menyatakan bahwa return on equity berpegaruh positif terhadap dividend payout ratio dinyatakan terdukung.

\section{Saran}


Berdasarkan kesimpulan di atas maka saran yang dapat diberikan adalah:

1. Untuk penelitian selanjutnya hendaknya menambah perusahaan sektor keuangan dalam penelitian, sehingga dapat mewakili semua perusahaan yang ada di Bursa Efek Indonesia.

2. Untuk penelitian selanjutnya hendaknya menambah variabel kontrol, sehingga dapat mengkontrol pengaruhvariabel independenterhadap kebijakan dividensepertifirm size.

3. Untuk penelitian selanjutnya hendaknya menggunakan proksi lainnya jika menggunakan variabel yang sama yaitu variabel growth opportunity, sehingga dapat melihat ada tidaknya perubahan hasil dalam penelitian.

\section{REFERENSI}

Andika, Septa Muhammad. (2017). Analisis Pengaruh Cash Convertion Cycle, Leverage, Net Working Capital, dan Growth Opportunity Terhadap Cash Holdings Perusahaan (Studi Kasus Pada Perusahaan Industri Barang Konsumsi Di Bursa Efek Indonesia Periode 2010-2015). JOM Fekon. Vol. 4, No. 1, Hal. 1479-1493.

Ang, Robert. (1997). Buku Pintar Pasar Modal. Mediasoft Indonesia.

Arilaha, Muhammad Asril. (2009). Pengaruh Free Cash Flow, Profitabilitas, Likuiditas, Dan Leverage Terhadap Kebijakan Dividen. Jurnal Keuangan dan Perbankan. Vol. 13, No. 1, Hal. 78-87.

Astuti, Meidinia dan Muhammadinah. (2018). Pengaruh Sales Growth dan Profitabilitas TerhadapDividen Payout Ratio pada Perusahaan Perbankan yang Terdaftar Di Bursa Efek Indonesia. Jurnal IEconomic. Vol. 4, No. 1, Hal. 251-260.

Awalina, Putri. (2016). Pengaruh Struktur Kepemilikan, Free Cash Flow, dan Return On Assets Terhadap Dividend Payout Ratio (Studi Empiris Pada Perusahaan Manufaktur yang Tercatat Di Bursa Efek Indonesia Periode 2012-2014). Jurnal Ilmiah Cendikia Akuntansi. Vol. 4, No. 1, Hal. 124-137.

Brigham, F. Eugene. (2006). Fundamental of financial Management. The Dryden Press: Holt-Sounders Japan

Deitana, Tita. (2009). Faktor-Faktor yang Mempengaruhi Kebijakan Pembayaran Dividen Kas. Jurnal Akuntansi Dan Bisnis. Vol. 11, No. 1, Hal. 57-64.

Dewi, Sisca Christianty. (2008). Pengaruh Kepemilikan Managerial, Kepemilikan Institusional, Kebijakan Hutang, Profitabilitas, dan Ukuran Perusahaan Terhadap Kebijakan Dividen. Jurnal Bisnis dan Akuntansi. Vol. 10, No. 1, Hal. 47-58.

Erfiana, Deka dan Anindya Ardiansari. (2016). Pengaruh Masalah Keagenan, Kebijakandividen, danVariabel Moderasi Growth Opportunity Terhadap Nilai Perusahaan. Management Analysis Journal. Vol. 5, No. 3, Hal. 244-256.

Fahmi, Irham. (2015). Analisis Laporan Keuangan. Bandung: Alfabeta.

Ghozali, Imam. (2016). AplikasiAnalisis Multivariate dengan Program IBM SPSS 23. Edisi 8. Badan Penerbit Universitas Diponegoro. Semarang.

Hardianto, B Josie Susilo. (2015). Freeport Indonesia Kembali Tak Bagikan Dividen. 25 November 2018. Diakses pada kompas.com.

https://ekonomi.kompas.com/read/2015/05/15/140528826/Freeport.Indonesia.Kembali.Tak.Bagik an.DIviden.

Hastuti, Rini Tri. (2018). Pengaruh EM, Size, ROE dan Lev Terhadap DPR Pada Perusahaan Manufaktur Yang Terdaftar Di Bei Tahun 2014-2016. Jurnal Ekonomi. Vol. 13, No. 2, Hal. 251-259.

Hidayati, Nur Dan Hadi Sunaryo. (2016). Dampak Corporate GovernanceTerhadap Keputusan Dividen(Literature Review Pada Negara-NegaraDi Asia, Australia dan Afrika). Jurnal Keuangan dan Perbankan. Vol.20, No.1, Hal. 32-41.

Husnan, Suad. (1998). Manajemen Keuangan Keputusan Investasi dan Pembelanjaan. Edisi Kedua. Yogyakarta: BPFE.

Huyen, Nguyen Thi. (2015). Factors Affecting the Dividend Payment Policy of the Listed Companies on the Ho Chi Minh Stock Market. Banking Academy. (12): 1-24.

Jensen, Michael C dan William H. Meckling. (1976). Theory of the Firm : Managerial Behavior, Agency Cost and Ownership Structure. Journal of Financial Economics.Vol. 3, No. 4, Hal.305-360. 
Kasmir. (2012). Anlisis Laporan Keuangan. Rajalawi Pers: Jakarta.

Meilani, Lia dan Dheasey Amboningtyas. 2017. Analisis Pengaruh Rasio Likuiditas, Leverage, dan Profitabilitas Terhadap Dividend Payout Ratio (DPR) Dengan Firm Size Sebagai Variabel Intervening pada Perusahaan Manufaktur yang Terdaftar Di Bursa Efek Indonesia Periode Tahun 2012-2016. Journal Of Management. Vol. 3, No. 3.

Myers, Melissa. and Bacon, Frank. (2002). The Determinants of Corporate Dividend Policy. Academy of Accounting and Financial Studies. Vol 7, No 1, Hal 105-110.

Nuringsih, Kartika. (2005). Analisis Pengaruh Kepemilikan Manajerial, Kebijakan Utang, ROA dan Ukuran PerusahaanTerhadap Kebijakan Dividen: Studi 1995-1996. Jurnal Akuntansi dan Keuangan Indonesia. Vol. 2, No. 2, Hal. 103-123.

Pasaribu, Rowland B. F., Dionysa Kowanda, dan Kholid Nawawi. (2014). Determinan Dividend Payout Ratio Pada Emiten LQ-45 Di Bursa Efek Indonesia. Jurnal Ekonomi dan Bisnis. Vol. 8, No. 1, Hal. $1-12$.

Pribadi, Anggit Satria dan R. Djoko Sampurno. (2012). Analisis Pengaruh Cash Position, Firm Size, Growth Opportunity, Ownership, dan Return On Asset Terhadap Dividend Payout Ratio. Diponegoro Journal Of Management. Vol. 1, No. 1, Hal. 212-211.

Prihatini, Puteri, Rahmiat dan Dessi Susanti. (2018). Pengaruh Profitabilitas, Investment Opportunity Set, dan Kepemilikan Manajerial Terhadap Kebijakan Dividen(Studi Pada Perusahaan Manufaktur yang Terdaftar Di Bursa Efek Indonesia Tahun 2013-2016). Jurusan Pendidikan Ekonomi Fakultas Ekonomi Universitas Negeri Padang. Vol. 1, No. 2, Hal. 298-307.

Putri, Eveilin Rosalina, Moh. Amin, dan M. Cholid Mawardi. (2019). Analisis Faktor-Faktor yang Mempengaruhi Kebijakan Pembagian Dividen pada Perusahaan yang Tergabung dalam Index JII Di Bursa Efek Indonesia tahun 2016-2018. Jurnal Ilmiah Riset Akuntansi. Vol. 8, No. 05, Hal. 8399.

Sari, N. K. A., dan Budiasih, I. G. A. (2016). Pengaruh Kepemilikan Managerial, Kepemilikan Institusional, FreeCash Flow dan Profitabilitas Pada Kebijakan Dividen. E-Jurnal Akuntansi Universitas Udayanal. Vol. 15, No. 3, Hal. 2439-2466.

Sartono, Agus. (2001). Manajemen Keuangan Teori dan Aplikasi. Edisi 4. Yogyakarta: BPFE

Simbolon, Kristina dan Djoko Sampurno. (2017). Analisis Pengaruh Firm Size, DER, Asset Growth, ROE, EPS, Quick Ratio dan Past Dividend terhadap Dividend Payout Ratio (Studi pada Perusahaan Manufaktur yang Terdaftar di BEI Tahun 2011-2015). Diponegoro Journal Ofmanagement.Vol. 6, No. 3, Hal. 1-13.

Sulaeman, Maman. (2018). Pengaruh Return On Equity (ROE) Terhadap dividend Payout Ratio (DPR) (Studi Pada Perusahaan Sektor Makanan dan Minuman yang Terdaftar di BEI). Ejournal UNIM. Vol. 01, No. 01, Hal. 73-88.

Susmiandini, Dini Dan Khoirotunnisa. (2017). Pengaruh Cash Ratio Terhadap Dividend Payout Ratio Pada Perusahaan Otomotif yang Terdaftar Di Bursa Efek Indonesia. Jurnal Studia Akuntansi dan Bisnis. Vol. 5, No. 3, Hal. 121-130.

Wachowicz, John M, Jr \& Van horne, James C. (1997). Prinsip-Prinsip Manajemen Keuangan. Buku satu. Edisi kesembilan. Alih bahasa Heru Sutojo. Jakarta: Salemba Empat.

Wijayanto, Edi dan Anggi Navulani Putri. (2018). Analisis Pengaruh Rasio Likuiditas, Rasio Leverage, Rasio Profitabilitas dan KepemilikanManajerial Terhadap Kebijakan Dividen. Jurnal Aktual Akuntansi Keuangan Bisnis Terapan. Vol. 1, No. 2, Hal. 105-118.

Wuisan, Felicia, Fransiskus Randa, dan Lukman. (2018). Pengaruh Struktur Kepemilikan Terhadap Kebijakan DividenPerusahaan. Jurnal Sistem Informasi, Manajemen dan Akuntansi. Vol. 16, No. 2, Hal. 119-141.

Yasa, Kadek Dwi Mahendra dan Ni Gusti Putu Wirawati. (2016). Pengaruh Net Profit Margin, Current Ratio, dan Debt To Equity Ratio Pada Dividend Payout Ratio. E-Jurnal Akunta Universitas Udayana.Vol.16, No 2, Hal. 921-950.

Yusuf,Muhammad dan Wa Ode Siti Rahmawati. (2016).Pengaruh Kepemilikan Manajerial dan Earning PerShare Terhadap Dividend Payout Ratio padaPerusahaan Manufaktur Yang ListingDi Bursa Efek Indonesia. Jurnal Mega Aktiva. Vol. 5, No. 1, Hal. 1-8. , 2019. www.idx.co.id. (Di akses tanggal 20 Agustus 2019) 